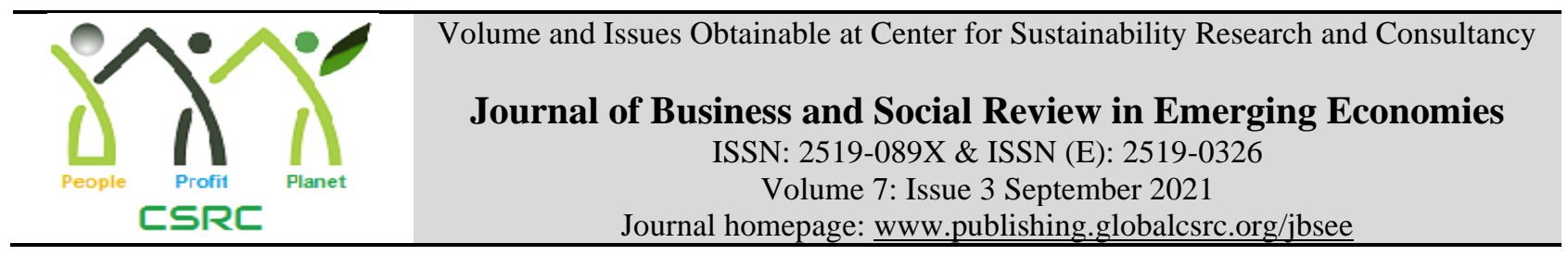

\title{
Impact of Protean Career Attitudes on Career Outcomes via Job Crafting Behavior: A Serial Mediation Model
}

\author{
*Muhammad Bilal Ahmad, Hailey College of Commerce, University of the Punjab, Lahore, \\ Pakistan \\ Mubbsher Munawar Khan, Hailey College of Banking and Finance, University of the Punjab, \\ Lahore, Pakistan \\ Muhammad Aamir, Hailey College of Commerce, University of the Punjab, Lahore, Pakistan
}

*Corresponding author's email: bilalaahmad220@gmail.com

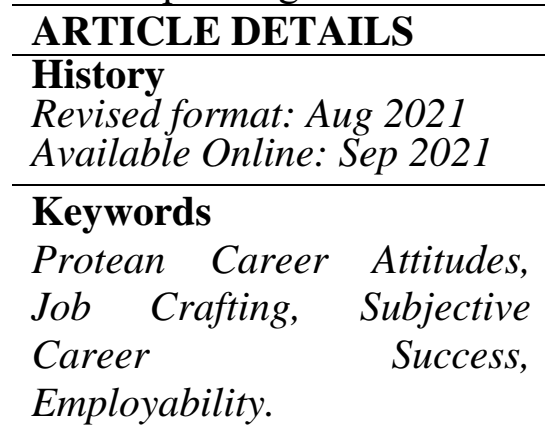

JEL Classification $M 1, M 2$

\begin{abstract}
Purpose: The study proposes that the individuals with protean career attitudes employ best work practices through job crafting behaviors and attain desired career outcomes. Therefore, the purpose of the study is to investigate the impact of protean career attitudes on career outcomes, i.e., Perceived Employability (PE) and Subjective Career Success (SCS) through job crafting behavior.

Methodology: The study has a quantitative, deductive research design that mainly focuses on the testation of the hypotheses. This study has been conducted on full-time faculty members of public and private sector Universities of Pakistan
\end{abstract}

Findings: The data from the employees working in the universities of Pakistan revealed that PCA has a positive impact on individual career outcomes. It was also found that there exists a pathway of serial mediation from job crafting towards perceived employability to achieve career success. The individuals who craft their jobs are more likely to enhance their employability, ultimately leading to career success. The study highlights the importance of PCA and Job Crafting behaviors, yet un-explored phenomena, for the employees for career development.

Implications: Employees who want to progress and develop their careers should actively engage in task crafting behavior in task crafting, relational crafting, or cognitive crafting.

(C) 2021 The authors, under a Creative Commons AttributionNonCommercial 4.0

\footnotetext{
Recommended citation: Ahmad, M. B., Khan, M. M. and Aamir, M. (2021). Impact of Protean Career Attitudes on Career Outcomes via Job Crafting Behavior: A Serial Mediation Model. Journal of Business and Social Review in Emerging Economies, 7 (3), 785-799.
} 


\section{Introduction}

Globalization has not only brought rapid changes in the new world order, but it also has made the traditionally employees' careers less promising by reducing job security and increasing unpredictability. Due to this labor market shift, work arrangements demand that more personally responsible workers develop their respective careers (Guan et al., 2019; Haenggli \& Hirschi, 2020). The labor market shift has also affected the academic career models, which have also been transformed from a collegial (professional) model to a more flexible managerial model. Universities have been commercialized with a more customer-focused orientation. Since then, the world of academe has been under the scrutiny of various researchers. Moreover, Due to the emerging unemployment rate from 5.1\% to 5.7\% (Bureau of Statistics, 2020), unemployment has become a severe concern in Pakistan. Despite producing many graduates yearly around but getting a desirable job is still a problem.

Moreover, existing employees are also are struggling to get up-gradation and to make their career successful. This is a very alarming situation Govt. seems to fail to cope up with this problematic issue. Likewise, these paradigm shifts have caused several career problems for academicians as well. HEC has set different standards and checks to evaluate the performance of the faculty members, and employees have to fulfill specific criteria including research publications, availing of research grants, number of PhDs or MPhil produced, etc., to meet set standards. It has become challenging to secure good jobs, but it has also become challenging to sustain employability. Therefore, there is a dire need to determine how employees can make their careers successful by enhancing their employability.

In this situation, there is pertinent to examine the modern career attitudes, i.e., characterized by the self-directed career with values-driven attitude and boundaryless career attitudes with the specifical relationship with the career outcomes, i.e., employability and career success (Wiernik $\&$ Kostal, 2019). These proactive career attitudes have also gained importance and are relevant to positive career growth (Wiernik \& Wille, 2017). These two career concepts, i.e., protean career by Hall (1996) and the boundaryless career by Arthur and Rousseau (1996), comprehended the paths through which individuals may attain career outcomes.

Protean employees are self-directed and prefer their personal goals and values (Briscoe \& Hall, 2006). There exist extent research related to proactive career attitudes and work-related outcomes like commitment, passion for work, and satisfaction (e.g., Redondo et al., 2019; Gulyani \& Bhatnagar, 2017), but according to Wiernik and Kostal (2019), there is a very scarce study related to their relationship with the individual career outcomes. There are very limited studies related to the impact of PCA on individual career outcomes like employability, objective career success, and subjective career success. Their results are also not conclusive within the context of Pakistan. So, there is still a grey area in which further investigating is needed to determine how PCA may help achieve career success. So. The study aims to investigate the impact of PCA on individual career outcomes, i.e., employability and subjective career success.

The study will also find how individuals may achieve this success by adopting protean career attitudes. To find the solution to this question, the study inculcates the job crafting behavior as a mediator through which individuals may achieve desired career outcomes. To examine this process, the study includes two theories, i.e., job crafting theory (Wrzesniewski \& Dutton, 2001) and career motivation theory (London, 1983), that might be helpful to understand the reason of how the individual may achieve their respective career outcomes by having protean career attitudes. Many studies highlight that job crafting behavior and motivation theory are certain positive factors that affect the employees' decision-making and behavior at work (Petrou et al., 2018). Still, there is scarce research that relates them with the literature of proactive career 
attitudes. London's (1983) theory provides insight into how a person's motivation affects achieving his desired outcomes in his career. Still, it does not offer practical guidelines to determine which behaviors must demonstrate to achieve said success. Job crafting fills this gap to propose that these are the job crafting behaviors through which employees can make themselves competitive and resourceful to achieve their career outcomes (Wrzesniewski \& Dutton, 2001). Based on these theories, the study proposed that job crafting behavior may be a strategy and a link between PCA and successful career outcomes. So, the purpose of the study is to investigate the impact of PCA on individual career outcomes through job crafting behavior.

\section{PCA, Employability, and Subjective Career Success}

PCA refers to the career mindset of the employees, which helps understand the employees' careers and working styles (Baruch, 2014). Generally, individuals with a PCA mindset do not depend on others, i.e., organization, for their career but rather on their own. According to the change, they remain self-directed, adaptable, and flexible according to the need (Hall, 2004). Similarly, PCA refers to a self-directed approach, and employees manage their respective careers according to their values (Hall et al., 2018). So, the PCA has two dimensions: self-directed and personal values-driven. Based on these two dimensions, individuals plan their career paths on their own and have their own unique set of career successes (Briscoe \& Hall, 2006).

Career success posits "positive psychological or Work-related achievements one accumulates as a result of his or her work experiences" (Judge et al. 1995, p. 03). Career Success has two dimensions: objective career success (OCS) and subjective Career success. OCS means tangible success in nature, measurable directly by indicators like salary, promotion, upward job enhancement, and increments (Judge et al., 1995). SCS is the employees' perception and personal evaluation regarding their career regarding career outcomes like satisfaction, work-life balance, perceived success (Shockley et al., 2016). Hence, it depends more on the individual career perception and personal goals or success vital for them (Seibert et al., 2001).

Several studies, especially in the meta-analysis based on 45,288 employees from different professions, it is found that PCA link with the objective career success indicators like promotion, salary, increments is not substantive (Wiernik and Kostal, 2019), and it is also supported that the employees with PCA pay great focus to your subjective career success (Stauffer et al., 2019). The study performed by Kundi et al. (2020) has found a significant positive impact of PCA on career satisfaction. Therefore, based on this literature, the study has proposed the following hypothesis:

\section{H1: There is a positive impact of PCA subjective career success}

Employability is vital for surviving in today's competitive work environment. Perceived employability refers to the employees' perception regarding their chances to get another same or better job inside or outside the organization ( Cuyper \& Witte, 2008). Further, employability has also transformed into two-dimension: objective and subjective employability (Emmerik et al., 2012). Employability plays a vital role in individuals' career development (Thijssen et al., 2008) and refers explicitly to the new career attitudes, i.e., PCA and BCA. Zafar and Mat ( 2012a) found a positive association between PCA and employability. Employability as the mediator of PCA has also been tested in the study. Studies have also found the direct relationship of PCA with employability (De Vos \& Soens, 2008; Volmer \& Spurk, 2011, Sultana, 2020), but most literature is closely related to general employability. Van den Broeck et al. (2014) has differentiated employability into internal, external, and quantitative, and qualitative employability. Based on the relationship found in the literature of PCA with generalized employability, the study has proposed the following;

\section{H2: There is a positive impact of PCA on the Perceived employability of the employees PCA \& Job Crafting}


The concept of the PCA careerists suggests that such individuals are more often involved in handling their respective career paths (Wiernik \& Kostal, 2019) by engaging themselves in proactive career behaviors, i.e., networking, planning, and chasing the opportunities (Li et al., 2019). According to Kostal and Wiernik (2017), Proactive individuals recognize the opportunities to excel and towards their career desires. Moreover, such employees are more interested in new work-related experiences and intend to work differently to develop new competencies through proactive work behaviors (Abessolo et al., 2017; Guan et al., 2019; Lo Presti et al., 2018). Job crafting is also a proactive work behavior. Job crafting theory (Wrzesniewski \& Dutton, 2001) also posits that the employees, involved in job crafting behavior, change their task boundaries, i.e., Task Crafting, develop new relationships at work, i.e., relational crafting, and change their perceptions related to the work, i.e., cognitive crafting.

Different studies have suggested the various antecedents of job crafting by the different researchers (e.g., Butucescu et al., 2020; Petrou et al., 2018). Similarly, the more proactive individuals in their career paths incline to engage in job crafting behavior at the workplace (Zhang \& Parker, 2019). Kundi et al. (2020) also tested and found a significant relationship between PCA and job crafting behavior. Based on these studies from the literature, the study proposed the following;

\section{H3: There is a positive impact of PCA on Job Crafting Job Crafting and Career Outcomes}

Kim and Beehr (2018) conducted a longitudinal study in the USA. They concluded that employees perceived positive work-related attitudes and achieved career-related outcomes through pro-active work behaviors, i.e., job crafting. Employees employ job crafting behavior, asserts control over their jobs, project a positive image at their workplace and accomplish career outcomes (Wrzesniewski and Dutton, 2001). According to Kim and Beehr (2017), job crafting significantly impacts employees' career success. Moreover, different studies posit that proactive behaviors are significantly associated with positive career outcomes (e.g., Kim et al., 2018; Cenciotti et al., 2017; Kundi et al., 2020). Based on this literature, this study also proposed the following hypothesis;

\section{H4: Job crafting has a positive impact on Employability H5: Job crafting has a positive impact on Subjective Career Success Job Crafting as a Mediator}

From the past studies, it is asserted that there exists a link between PCA and individual career outcomes, i.e., satisfaction, success, commitment, engagement (e.g., Li et al., 2019; Lo Presti et al., 2018; Ngo \& Hui, 2018; Kundi et al., 2020). However, there is still an un-clarity regarding the mechanism through which such outcomes have been achieved by practicing PCA. London's (1983) theory of motivation posits the importance of positive encouragement to achieve desired results through certain behaviors, but those behaviors are not cleared yet. Therefore, this study addresses this gap by introducing job crafting behavior as a mediator between PCA and career outcomes. The study proposed that job crafting behavior is the proactive career behavior through which individuals achieve career outcomes. Therefore, the following hypothesis is proposed in the study;

\section{H6: There is an impact of PCA on career outcomes a) Employability b) Subjective career Success through job crafting behavior.}

Although in the studies, there is a neglect of the indirect relationship of the PCA on Subjective career success through job crafting and perceived employability. There are few studies in which indirect serial mediation of career commitment and job crafting is tested (Kundi et al., 2020), but still, there is a scarcity of research on this area. To address this gap, the study has proposed a serial mediation of job crafting and employability between PCA and Subjective Career Success. 


\section{H7: PCA is positively related to subjective career success through job crafting and employability}

\section{Methodology}

The study has a quantitative, deductive research design that mainly focuses on the testation of the hypotheses. In quantitative research design, it is a survey study, and the data is collected through questionnaires. This is a cross-sectional study as the data is collected at one single time only. This study has been conducted on full-time faculty members of public and private sector Universities of Pakistan. The unit of analysis is the individual in the study.

\begin{tabular}{|c|c|c|c|c|c|c|}
\hline \multicolumn{7}{|c|}{$\begin{array}{l}\text { Total Universities of Pakistan (HEC Approved) }=177 \\
\text { First Stratification (Province Wise) }\end{array}$} \\
\hline & Punjab & Sindh & KPK & Baluchistan & Federal & Total \\
\hline Universities & 61 & 53 & 35 & 08 & 20 & 177 \\
\hline \multicolumn{7}{|c|}{ Second Level Stratification (Sector Wise) } \\
\hline & Punjab & Sindh & KPK & Baluchistan & Federal & \\
\hline Public & 35 & 23 & 25 & 7 & 14 & 104 \\
\hline Private & 26 & 30 & 10 & 1 & 06 & 73 \\
\hline \multicolumn{7}{|c|}{ Proportionate $10 \%$ of universities from each stratum } \\
\hline Public & 4 & 2 & 2 & 1 & 2 & 11 \\
\hline \multirow[t]{2}{*}{ Private } & 3 & 3 & 1 & --- & 1 & 8 \\
\hline & 7 & 5 & 3 & 1 & 3 & 19 \\
\hline
\end{tabular}

Proportionate Stratified sampling has been used to select the sample, and provinces based on five strata have been made, i.e., Punjab, KPK, Sindh, Baluchistan, and Islamabad. In each province, on the proportion of $10 \%$ universities have been selected from all the provinces. According to the HEC, there are 177 universities, of which 104 are public, and 73 universities are private (list attached). The selected number of universities have been chosen from the capital of each province.

A total of 600 questionnaires have been distributed among the permanent faculty members of the universities, and 490 have been returned. Among 490 questionnaires, some questionnaires have been dropped due to missing data, and finally, 435 questionnaires' data has been used to run the analysis. The response rate was $72 \%$.

\section{Instruments and Measurement}

All variables will be measured by using modify/adopted scales originally developed by the following researchers. All the items have been measured on 05 points Likert scale.

\section{Protean Career Attitude}

PCA is measured by using Porter et al., (2016) scale with six items. "(E.g., In general, I independently manage my career)."

\section{Boundaryless Career Attitude}

BCA would be measured by using Porter et al., (2016) scale with six items "(e.g., I enjoy working with people outside of my organization)."

\section{Job Crafting}

In this study, Job crafting uses a Multi-dimensional Construct, i.e., Relational, Cognitive, and Task. Job Crafting is measured by using Slemp \& Vella-Brodrick, (2013) 5 points Likert scale. This scale has overall 15 items "(e.g., I choose to take on additional tasks at work)."

\section{Subjective Career Success}

SCS is measured by Pan \& Zhou (2015) scale with three dimensions, i.e., external compensation (EC), Intrinsic fulfillment (IF), and work-life balance (WLB). Overall, the scale has ten items, 04 items for IF, and the rest have 03 items. "(e.g., I like my job and I am happy during my work)." 


\section{Employability}

De Cuyper and De Witte (2008) perceived employability scale with 04 dimensions and 04 items for each dimension have been used to measure the perceived employability in the study "I can change jobs easily if I wanted)."

\section{Control Variables}

The study has taken demographic variables, i.e., Age, University type, Organizational size, gender, organization age, as control variables linked to the Individual career Outcomes.

\section{Marker Variable}

The study has also inculcated the Fear of Covid-19 with 06 items as a marker variable. This variable is not related to the other variables in the model, and biases have been tackled by this common method. There is no CMV issue present in the data.

\section{Results \& Analysis}

Data is analyzed through structural equation modeling (SEM) using Smart-PLS 3.0. Both measurement and structural models have been run as suggested by the literature (Chin, 2000; Henseler et al., 2009; Anderson \& Gerbing, 1988). First of all, a measurement model has been run to check the reliability, validity, effect sizes, and R square of the model; after that structural model has been run to test the hypotheses.

\section{Demographics}

\begin{tabular}{|c|c|c|c|}
\hline & Category & Frequency & Percentage \\
\hline \multirow[t]{3}{*}{ Gender } & Male & 260 & 59 \\
\hline & Female & 175 & 41 \\
\hline & Total & 435 & 100 \\
\hline \multirow{3}{*}{ Marital Status } & Single & 122 & 28 \\
\hline & Married & 313 & 72 \\
\hline & Total & 435 & 100 \\
\hline \multirow{4}{*}{ Qualification } & MPhil & 144 & 33 \\
\hline & $\mathrm{PhD}$ & 226 & 52 \\
\hline & Post PhD & 65 & 15 \\
\hline & & 435 & 100 \\
\hline \multirow[t]{5}{*}{ Age } & $21-30$ & 148 & 34 \\
\hline & $31-40$ & 165 & 38 \\
\hline & $41-50$ & 83 & 19 \\
\hline & above 50 & 39 & 9 \\
\hline & & 435 & 100 \\
\hline \multirow{6}{*}{ Overall Exp } & 1 to 5 & 139 & 32 \\
\hline & 6 to 10 & 144 & 33 \\
\hline & 11 to 15 & 70 & 16 \\
\hline & 16 to 20 & 44 & 10 \\
\hline & above 20 & 39 & 9 \\
\hline & & 435 & 100 \\
\hline \multirow{3}{*}{ Qualification } & Lecturer & 165 & 38 \\
\hline & Assistant Professor & 161 & 37 \\
\hline & Associate Professor & 65 & 15 \\
\hline
\end{tabular}


University

Public
Private

\section{Measurement Model (MM)}

In the MM, reliability, along with the validity of the constructs, has been measured. Loadings of all the items are within the threshold level, the value of more than 0.7 (Henseler et al., 2009) with no $<0.4$ (Churchill, 1979) is recommended. Some items have been deleted from the model due to low factor loading. The table shows that all the items loadings are between the ranges from 0.591 to 0.8. After that, inter-consistency reliability was measured by both the Cronbach Alpha and composite reliability. The minimum acceptable value is 0.6 (Cronbach, 1951) and 0.7 (Nunnally and Bernstein, 1994), respectively, and all matters of constructs are above the threshold value (i.e.,>0.7).

Convergent validity has been measured by the AVE values, more significant than the threshold level, i.e., >0.5. The table shows the value of AVE above 0.5 (Fornell \& Larcker, 1981), which means that the constructs do not have any convergent validity issue. Discriminant validity has been tested by the Fornell and Larcker (1981) criterion as well as with the cross-loadings of the indicators (Sarstedt et al., 2014). The square root of AVE values must be greater than the values in the diagonal, and the same has been reported in the table. As shown in the table, cross-loadings show that item-level discriminant validity has been established in the model. Every item showed higher loadings on their constructs than other constructs. HTMT criteria (Henseler, Hubona, \& Ray, 2016) have also established the discriminant validity as all the correlations in the model are significantly less than threshold criteria, i.e., $<1$.

\section{Measurement Models}

\begin{tabular}{|c|c|c|c|c|c|}
\hline tent Variable & Indicators & Loadings & Alpha & $\begin{array}{l}\text { Composite } \\
\text { Reliability }\end{array}$ & AVE \\
\hline
\end{tabular}

\begin{tabular}{lllllll}
\hline PCA & SD1 & 0.773 & 0.800 & 0.861 & 0.559 & Yes \\
& SD3 & 0.812 & & & \\
& SD4 & 0.847 & & & \\
& VD2 & 0.591 & & & \\
& VD3 & 0.719 & & & \\
\hline JC & CC3 & 0.702 & 0.845 & 1.845 & 2.845 & Yes \\
& CC4 & 0.788 & & & \\
& CC5 & 0.718 & & & \\
& RC1 & 0.761 & & & \\
& RC2 & 0.796 & & & \\
& RC3 & 0.736 & & & \\
\hline SCS & IF1 & 0.796 & 0.834 & 0.883 & & \\
& IF2 & 0.719 & & & & \\
& IF3 & 0.802 & & & & \\
& WLB2 & 0.758 & & & & \\
& WLB3 & 0.799 & & & & \\
\end{tabular}




\begin{tabular}{lllllll}
\hline Employability & ILM1 & 0.829 & 0.863 & 0.907 & 0.709 & Yes \\
& ILM2 & 0.896 & & & & \\
& ILM3 & 0.847 & & & & \\
& ILM4 & 0.794 & & & & \\
\hline
\end{tabular}

\section{Fornell \& Larcker Criterion}

\begin{tabular}{lllll}
\hline & Employ & JC & PCA & SCS \\
\hline Employ & $\mathbf{0 . 8 4 2}$ & & & \\
JC & 0.63 & $\mathbf{0 . 7 5 1}$ & & \\
PCA & 0.666 & 0.628 & $\mathbf{0 . 7 4 7}$ & $\mathbf{0 . 7 7 5}$ \\
SCS & 0.665 & 0.686 & 0.694 & \\
\hline
\end{tabular}

\section{Cross Loadings}

\begin{tabular}{lllll}
\hline & Employ & JC & PCA & SCS \\
\hline ILM2 & $\mathbf{0 . 8 9 6}$ & 0.524 & 0.568 & 0.594 \\
ILM3 & $\mathbf{0 . 8 4 7}$ & 0.443 & 0.491 & 0.459 \\
ILM1 & $\mathbf{0 . 8 2 9}$ & 0.603 & 0.656 & 0.629 \\
ILM4 & $\mathbf{0 . 7 9 4}$ & 0.527 & 0.501 & 0.529 \\
\hline CC4 & 0.524 & $\mathbf{0 . 7 8 8}$ & 0.484 & 0.524 \\
RC1 & 0.517 & $\mathbf{0 . 7 6 1}$ & 0.49 & 0.569 \\
CC3 & 0.478 & $\mathbf{0 . 7 0 2}$ & 0.411 & 0.397 \\
RC3 & 0.464 & $\mathbf{0 . 7 3 6}$ & 0.465 & 0.497 \\
RC2 & 0.449 & $\mathbf{0 . 7 9 6}$ & 0.468 & 0.532 \\
CC5 & 0.405 & $\mathbf{0 . 7 1 8}$ & 0.503 & 0.555 \\
\hline SD1 & 0.511 & $\mathbf{0 . 7 6 4}$ & 0.536 \\
SD3 & 0.493 & 0.597 & $\mathbf{0 . 8 1 4}$ & 0.603 \\
SD4 & 0.615 & 0.468 & $\mathbf{0 . 8 4 3}$ & 0.559 \\
VD3 & 0.486 & 0.411 & $\mathbf{0 . 7 3 6}$ & 0.552 \\
VD2 & 0.511 & 0.298 & $\mathbf{0 . 5 4 4}$ & 0.262 \\
\hline IF1 & 0.339 & 0.531 & 0.552 & $\mathbf{0 . 7 9 6}$ \\
IF2 & 0.588 & 0.499 & 0.444 & $\mathbf{0 . 7 1 9}$ \\
IF3 & 0.513 & 0.536 & 0.637 & $\mathbf{0 . 8 0 2}$ \\
WLB2 & 0.48 & 0.576 & 0.497 & $\mathbf{0 . 7 5 8}$ \\
WLB3 & 0.449 & 0.52 & 0.549 & $\mathbf{0 . 7 9 9}$ \\
\hline
\end{tabular}

\begin{tabular}{llll}
\hline HTMT & & & \\
\hline & Employ & JC & PCA \\
\hline Employ & & & \\
JC & 0.728 & & \\
PCA & 0.781 & 0.744 & 0.822 \\
SCS & 0.774 & 0.814 & \\
\hline
\end{tabular}

\begin{tabular}{ll}
\hline Outer VIF Values & \\
\hline & VIF \\
\hline CC3 & 2.060 \\
CC4 & 2.347 \\
CC5 & 1.560 \\
ET2 & 1.657 \\
\hline
\end{tabular}




\begin{tabular}{ll}
\hline ET4 & 1.661 \\
IF1 & 2.069 \\
IF2 & 1.893 \\
IF3 & 1.812 \\
ILM1 & 1.987 \\
ILM2 & 2.720 \\
ILM3 & 2.222 \\
ILM4 & 1.797 \\
INFO1 & 2.413 \\
INFO2 & 2.178 \\
RC1 & 1.876 \\
RC2 & 2.330 \\
RC3 & 1.867 \\
SD1 & 1.709 \\
SD3 & 1.850 \\
SD4 & 2.219 \\
SOC4 & 1.915 \\
SOC5 & 2.266 \\
VD2 & 1.446 \\
VD3 & 1.749 \\
WLB2 & 1.947 \\
WLB3 & 2.133 \\
\hline
\end{tabular}

\section{f Square}

\begin{tabular}{lllll}
\hline & Employ & JC & PCA & SCS \\
\hline Employ & & & & 0.071 \\
JC & 0.659 & & & 0.147 \\
PCA & & 0.65 & 0.135 \\
SCS & & & \\
\hline
\end{tabular}

\begin{tabular}{lll}
\hline & R Square & R Square Adjusted \\
\hline Employ & 0.519 & 0.516 \\
JC & 0.393 & 0.392 \\
SCS & 0.62 & 0.613 \\
\hline
\end{tabular}

\section{Measurement Model}




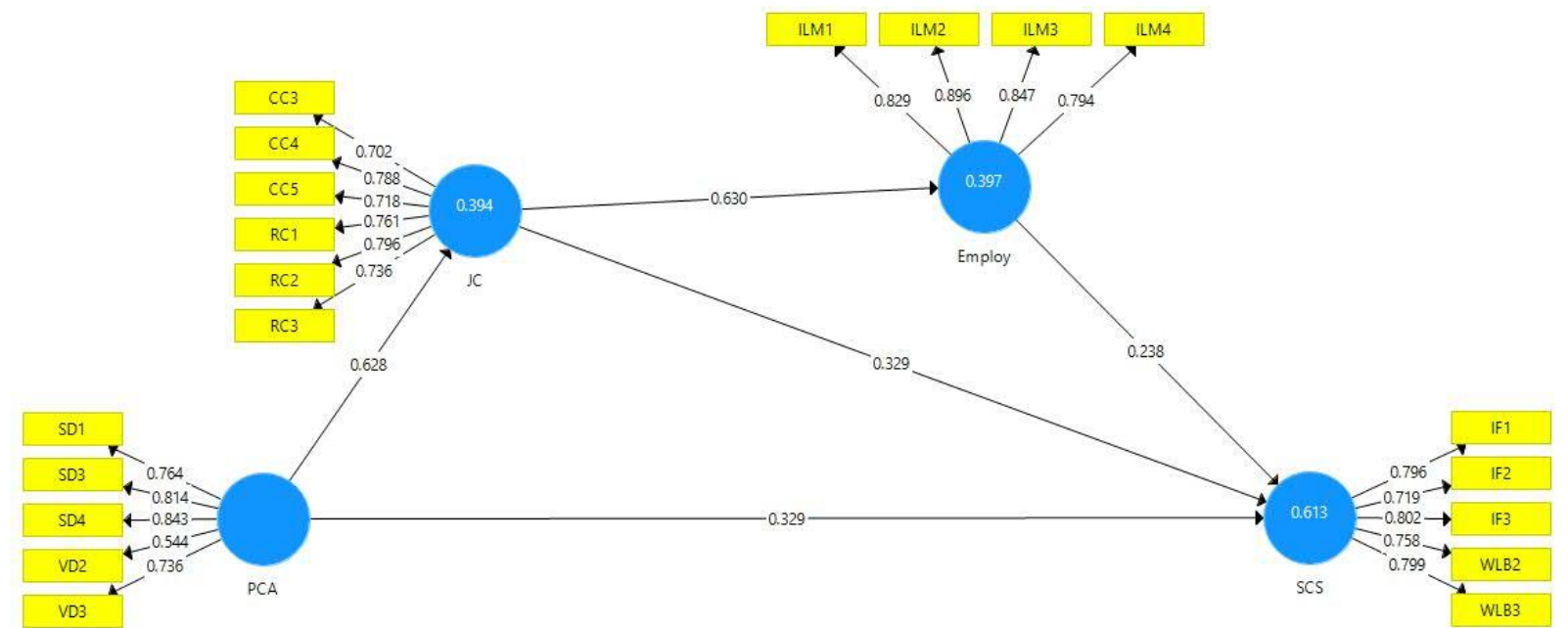

\section{Structural Model (SM)}

After the sound MM, the next step SM has been statistically verified, and the hypothesis is tested. The bootstrapping procedure with 5000 sub-samples (Ringle, Wende,\&Becker, 2015) was performed in Smart PLS-SEM 3.0. The results of the bootstrapping are mentioned in the table below. According to the result, all direct hypothesis has been supported at $1 \%$ significant level. The variations explained by the perceived employability, J.C., and SCS are 51\%, 39\%, and 62\%, respectively.

\section{The Predictive Relevance $\mathbf{Q}^{2}$}

In addition, with the predictive accuracy of the model explained by the $\mathrm{R}^{2}$. Predictive relevance $\mathrm{Q}^{2}$ has also been calculated in the model. The threshold value of $\mathrm{Q}^{2}$ is greater than the ZERO (Hair, Hult, Ringle,\&Sarstedt, 2017). In the model, $\mathrm{Q}^{2}$ of all the constructs is above the minimum threshold. The $\mathrm{f}^{2}$ of all the exogenous constructs has also been calculated to assert the specific effect of each construct on the relevant endogenous construct (Hair, Sarstedt, et al., 2014). The values of "0.02", "0.15", and "0.35" indicate small, medium, and large effects, respectively. J.C. and PCA have a moderate effect size on Subjective Career Success, and employability has a weak effect size, i.e., 0.07. The rest of all have substantial effect sizes, as detail shown in the table.

\section{Hypothesis-Testing (Direct Effects)}

\begin{tabular}{lllll}
\hline Hypotheses & Paths & Path Coefficients & T Statistics & P Values \\
H2 & PCA $->$ SCS & $0.329^{*}$ & 6.413 & 0 \\
H3 & PCA -> Employ & $0.448^{*}$ & 11.073 & 0 \\
H4 & PCA -> JC & $0.627^{*}$ & 20.864 & 0 \\
H5 & JC -> Employ & $0.349^{*}$ & 8.928 & 0 \\
& JC -> SCS & $0.317^{*}$ & 6.403 & 0 \\
& Not Hypothesized & & & \\
& Age -> SCS & -0.017 & 0.561 & 0.575 \\
& Gender -> SCS & 0.059 & 1.96 & 0.05 \\
& Org. Age -> SCS & -0.033 & 1.145 & 0.252 \\
& Org. SIze -> SCS & -0.045 & 1.512 & 0.131 \\
& University_-> SCS & -0.051 & 1.597 & 0.11 \\
\hline
\end{tabular}

Note: $* *$, indicate at $1 \%, 5 \%$, respectively.

\section{Mediation Testing}

The mediation has been tested through bootstrapping with 5000 sub-samples in PLS-SEM 3.0 as 
advocated by Hair et al. (2017) and Zhao, Lynch, and Chen (2010) despite using Baron and Kenny (1986) approach for mediation testation. Hair et al. (2017) proposed two different types of Non-mediation and three different categories of mediation as offered in the table;

\begin{tabular}{|l|l|}
\hline No Direct, NO Indirect Effect & No-effect No Mediation \\
\hline Direct only, No Indirect & Direct Only Non- Mediation \\
\hline "Direct and Indirect Both Significant in the same direction" & Complementary Partial Mediation \\
\hline $\begin{array}{l}\text { "Direct and Indirect effects are both significant but in the } \\
\text { opposite direction." }\end{array}$ & Competitive partial mediation \\
\hline "The only indirect effect is significant." & Full Mediation \\
\hline
\end{tabular}

The mediation result table showed that $\mathrm{H6a}, \mathrm{H} 6 \mathrm{~b}$, and $\mathrm{H} 7$ all are statistically significant, as well as direct path from PCA -> SCS is also significant. That means there exists a complementary partial mediation, as well as Complementary serial mediation, also exist in the model.

\section{Mediation Results}

\begin{tabular}{llllll} 
& & \multicolumn{3}{c}{ Total Effect } \\
\hline Hypotheses & Paths & Coefficients & T Statistics & Coefficients & P value \\
\hline H6a & PCA -> JC -> Employ & 0.219 & 7.886 & 0.349 & 0 \\
H6b & PCA -> JC -> SCS & 0.199 & 6.067 & 0.684 & 0 \\
H7 & PCA -> JC -> Employ -> SCS & 0.051 & 4.126 & 0.684 & 0 \\
\hline
\end{tabular}

Note: **, * indicate at $1 \%, 5 \%$, respectively.

$Q^{2}$

\begin{tabular}{lll}
\hline & Redundancy & Communality \\
EMPLOY & 0.356 & 0.507 \\
JC & 0.218 & 0.388 \\
PCA_ & - & 0.351 \\
SCS & 0.365 & 0.401 \\
\hline
\end{tabular}

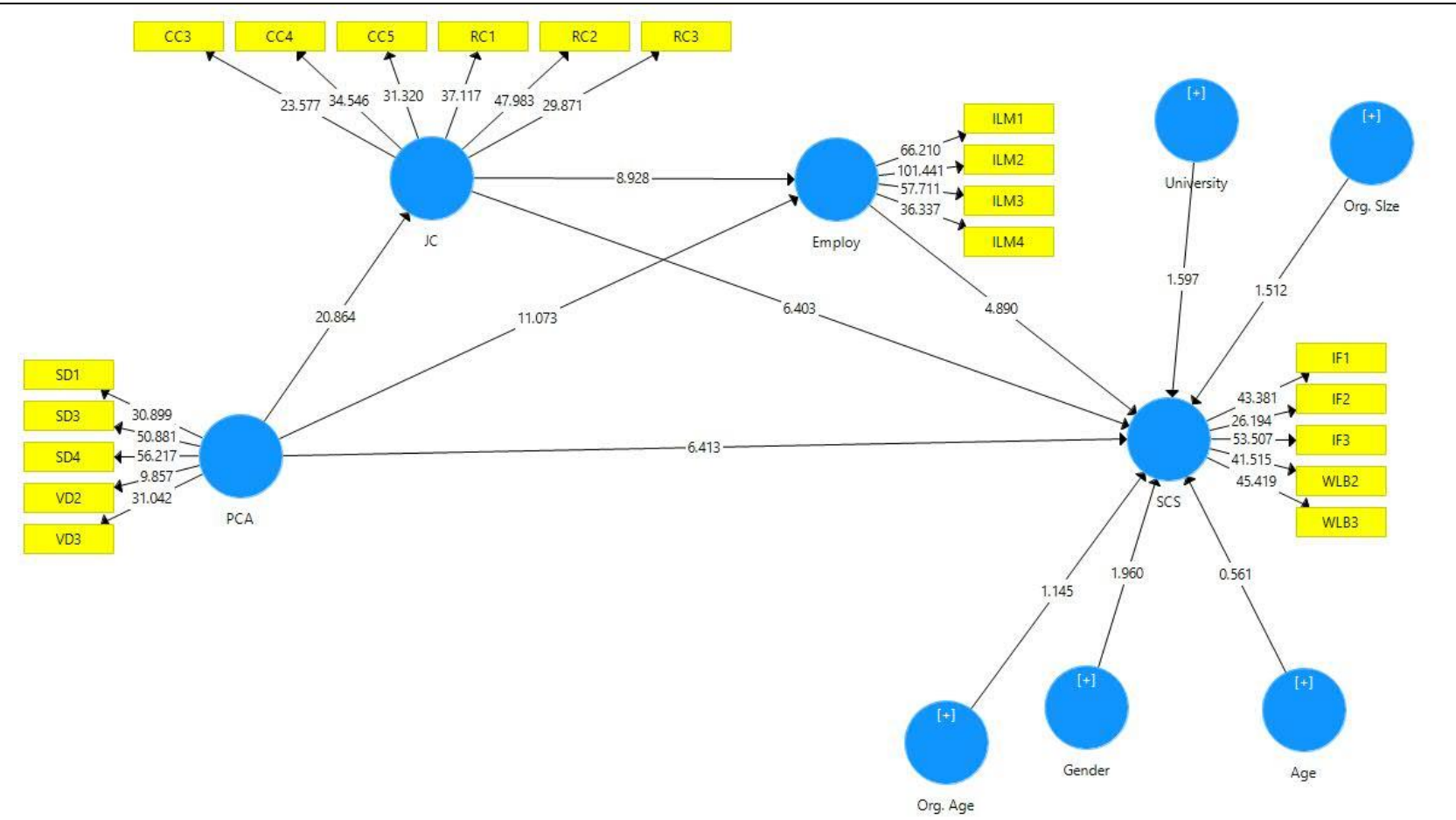

\section{Structural Model}

\section{Discussion and Conclusion}

The PLS-SEM analysis confirms the relationships of proactive career success with job crafting, employability, and subjective career success. Although the individual career success area has gained significant attention in research (Spurk et al., 2019), a gap still exists in the process 
induced by the PCA to achieve work-related outcomes (Wiernik \& Kostal, 2019). The study's main objective was to understand the process of achieving career success through proactive career behaviors; therefore, job crafting behavior has been considered. The current findings are similar to the conclusions of the research conducted in different countries and contexts (e.g., Kundi et al., 2020; Stauffer et al., 2019; Lo Presti et al., 2018). These studies also found the significant impact of PCA on Subjective career success, job crafting, commitment, and serial mediation between PCA and subjective career success but through career commitment. In this study, the PCA relationship is statistically supported through serial mediation from Job crafting and employability to subjective career success.

The role of job crafting is pivotal while depicting career success (Dubbelt et al., 2019; Wang et al., 2020), and the importance of job crafting for university faculty members is well established. Employees who want to progress and develop their careers should actively engage in task crafting behavior in task crafting, relational crafting, or cognitive crafting.

The study has contributed to the literature as it provides a mechanism of job crafting as an effective strategy to attain career goals in life. The findings of the study contribute to the literature on job crafting and career-related outcomes. Further, provide insight to the researchers to unexplored areas of the related kind. The study provides deeper insight regarding understanding the role of PCA mindset employees while developing careers. Finally, the study has extended the career understanding by directly examining the PCA to Career success, job crating, and career motivation theory. The study empirically tested that why and how job crafting plays an essential role in individual career development.

\section{Limitation and Future Direction}

The study has several limitations in that it has used a uni-dimension construct of job crafting. In the future, job crafting dimensions can be tested separately to check their effect on career outcomes. Secondly, data has been collected at one time. In the future, longitudinal studies can be conducted to see the impact of practicing PCA through job crafting on the employees' career success, and it will become a sustainable career.

Career shocks have not been included in the study to find out their impacts on individual career life. In the future, career shocks can be used as a moderator to predict career success. The study has conducted on University employees in Pakistan in the future. The study can also be conducted on other services sectors to check how this model works in those particular sectors. The role of gender has not been tested in the study, as females comparatively with men, have less freedom, and the model may work differently in males and females separately. In the future, a multi-group model may be tested to check gender role in the success.

\section{Conclusion}

It is concluded that employees' protean career attitudes tend to achieve their respective career success and enhance their employability by practicing the job crafting behavior at their workplace.

\section{References}

Abessolo, M., Hirschi, A., \& Rossier, J. (2017). Work values underlying protean and boundary less career orientations. Career Development International, 22(3), 241-259. https://doi.org/10.1108/CDI-10-2016-0167

Anderson, J. C., \& Gerbing, D. W. (1988). Structural equation modeling in practice: A review and recommended two-step approach. Psychological bulletin, 103(3), 411-423

Arthur, M. B., \& Rousseau, D. M. (1996). A career lexicon for the 21st century. Academy of Management Perspectives, 10(4), 28-39 
Baron, R., \& Kenny, D. (1986). The moderator-mediator variable distinction in social psychological research. Journal of Personality and Social Psychology, 51(6), 1173e1182

Baruch, Y. (2014). The development and validation of a measure for protean career orientation.

Briscoe, J. P., \& Hall, D. T. (2006). The interplay of boundary less and protean careers: Combinations and implications. Journal of Vocational Behavior, 69(1), 4-18. https://doi.org/10.1016/j.jvb.2005.09.002

Briscoe, J. P., Hall, D. T., \& DeMuth, R. L. F. (2006). Protean and boundary less careers: An empirical exploration. Journal of vocational behavior, 69(1), 30-47

Butucescu, A., Zanfirescu, A. Ș., \& Iliescu, D. (2020). The whys and wherefores of going the extra-mile as public health workers. Personality and Individual Differences, 153, 109646

Cenciotti, R., Alessandri, G., \& Borgogni, L. (2017). Psychological capital and career success over time: The mediating role of job crafting. Journal of Leadership \& Organizational Studies, 24(3), 372-384.

Chin, W. (2000, December). Partial least squares for IS researchers: an overview and presentation of recent advances using the PLS approach. In ICIS (Vol. 2000, pp. 741-742).

Churchill Jr, G. A. (1979). A paradigm for developing better measures of marketing constructs. Journal of marketing research, 64-73

Cronbach, L. J. (1951). Coefficient alpha and the internal structure of tests. Psychometrika, 16(3), 297-334

De Cuyper, N., \& De Witte, H. (2008). Gepercipieerde kans op een baan versus een betere baan: relaties met arbeidstevredenheid en welzijn. Gedrag en Organisatie.

De Cuyper, N., \& De Witte, H. (2008). Perceived chance of alternative employment versus better employment: Associations with job satisfaction and well-being. GEDRAG \& ORGANISATIE, 21(4), 475-492.

De Vos, A., \& Soens, N. (2008). Protean attitude and career success: The mediating role of selfmanagement. Journal of Vocational behavior, 73(3), 449-456

Dubbelt, L., Demerouti, E., \& Rispens, S. (2019). The value of job crafting for work engagement, task performance, and career satisfaction: Longitudinal and quasi-experimental evidence. European Journal of Work and Organizational Psychology,28(3), 300-314. https://doi.org/10.1080/1359432X.2019.1576632

Emmerik, I. J. H. v., Schreurs, B., Cuyper, N. d., Jawahar, I. M., \& Peeters, M. C. W. (2012). The route to employability: Examining resources and the mediating role of motivation. Career Development International, 17(2), 104-119. doi: doi:10.1108/13620431211225304

Fornell, C., \& Larcker, D. F. (1981). Evaluating structural equation models with unobservable variables and measurement error. Journal of marketing research, 39-50

Guan, Y., Arthur, M. B., Khapova, S. N., Hall, R. J., \& Lord, R. G. (2019). Career boundarylessness and career success: A review, integration and guide to future research. Journal of Vocational Behavior, 110, 390-402.

Gulyani, G., \& Bhatnagar, J. (2017). Mediator analysis of passion for work in Indian millennials. Career Development International.

Haenggli, M., \& Hirschi, A. (2020). Career adaptability and career success in the context of a broader career resources framework. Journal of vocational behavior, 103414.

Hair, J. F., Hult, G. T. M., Ringle, C., \& Sarstedt, M. (2014).A primer on partial least squares structural equation modeling. Thousand Oaks, CA: Sage

Hair, J. F., Hult, G. T. M., Ringle, C., \& Sarstedt, M. (2017).A primer on partial least squares structural equation modeling (PLS-SEM)(2nd ed.). Thousand Oaks: Sage.

Hall, D. T. (1996). Protean careers of the 21st century. Academy of Management Perspectives, 10(4), 8-16. https://doi.org/10.5465/ame.1996.3145315

Hall, D. T., Yip, J., \& Doiron, K. (2018). Protean careers at work: Self-direction and values orientation in psychological success. Annual Review of Organizational Psychology and Organizational Behavior, 5, 129-156. https://doi.org/10.1146/annurev-orgpsych-032117104631 
Henseler, J., Hubona, G., \& Ray, P. (2016). Using PLS path modeling in new technology research: Updated guidelines. Industrial Management \&Data Systems, 116(1), 2e20.

Henseler, J., Ringle, C. M., \& Sinkovics, R. R. (2009). The use of partial least squares path modeling in international marketing. Advances in international marketing, 20(1), 277-319

International Journal of Human Resource Management, 25(19), 2702-2723. https://doi.org/10.1080/ 09585192.2014.896389

judge, T., Cable, D., Boudreau, J., \& Bretz, R. (1995). An empirical investigation of the predictors of executive career success. Personnel Psychology, 48(3), 485-519. https://doi.org/10.1111/j.1744-6570. 1995. tb01767.x

Kim, H., Im, J., Qu, H., \& NamKoong, J. (2018). Antecedent and consequences of job crafting: an organizational level approach. International Journal of Contemporary Hospitality Management

Kim, M., \& Beehr, T. A. (2017). Directing our own careers, but getting help from empowering leaders. Career Development International.

Kim, M., \& Beehr, T. A. (2018). Can empowering leaders affect subordinates' well-being and careers because they encourage subordinates' job crafting behaviors?. Journal of Leadership \& Organizational Studies, 25(2), 184-196.

Kundi, Y. M., Hollet-Haudebert, S., \& Peterson, J. (2020). Linking Protean and Boundaryless Career Attitudes to Subjective Career Success: A Serial Mediation Model. Journal of Career Assessment, 1069072720959782.

Li, H., Ngo, H. Y., \& Cheung, F. (2019). Linking protean career orientation and career decidedness: The mediating role of career decision self-efficacy. Journal of Vocational Behavior. https://doi.org/10.1016/j. jvb.2019.103322

Lo Presti, A., Pluviano, S., \& Briscoe, J. P. (2018). Are freelancers a breed apart? The role of protean and boundaryless career attitudes in employability and career success. Human Resource Management Journal, 28(3), 427-442.

London, M. (1983). Toward a theory of career motivation. Academy of management review, 8(4), 620-630.

Ngo, H. Y., \& Hui, L. (2018). Individual orientations and career satisfaction: The mediating roles of work engagement and self-efficacy. Journal of Career Development,45(5), 425-439. https://doi.org/10.1177/089 4845317706759

Nunnally, J. C., \& Bernstein, I. H. (1994). Psychometric Theory 3rd ed McGraw-Hill New York

Pan, J., \& Zhou, W. (2015). How do employees construe their career success: An improved measure of subjective career success. International Journal of Selection and Assessment, 23(1), 45-58.

Petrou, P., Demerouti, E., \& Schaufeli, W. B. (2018). Crafting the change: The role of employee job crafting behaviors for successful organizational change. Journal of Management, 44(5), 1766-1792.

Petrou, P., Demerouti, E., \& Schaufeli, W. B. (2018). Crafting the change: The role of employee job crafting behaviors for successful organizational change. Journal of Management, 44(5), 1766-1792

Porter, C., Woo, S. E., \& Tak, J. (2016). Developing and validating short form protean and boundaryless career attitudes scales. Journal of Career Assessment, 24(1), 162-181. https://doi.org/10.1177/1069072714565775

Redondo, R., Sparrow, P., \& Hernández-Lechuga, G. (2019). The effect of protean careers on talent retention: examining the relationship between protean career orientation, organizational commitment, job satisfaction and intention to quit for talented workers. The International Journal of Human Resource Management, 1-24.

Retrieved fromhttp://www.smartpls.com

Ringle, C. M., Wende, S., \& Becker, J.-M. (2015).SmartPLS 3. B€ onningstedt: SmartPLS.

Seibert, S. E., Kraimer, M. L., \& Liden, R. C. (2001). A social capital theory of career success. Academy of Management Journal, 44(2), 219-237. https://doi.org/10.5465/3069452 
Shockley, K. M., Ureksoy, H., Rodopman, O. B., Poteat, L. F., \& Dullaghan, T. R. (2016). Development of a new scale to measure subjective career success: A mixed-methods study. Journal of Organizational Behavior, 37(1), 128-153. https://doi.org/10.1002/job.2046

Slemp, G. R., \& Vella-Brodrick, D. A. (2013). The Job Crafting Questionnaire: A new scale to measure the extent to which employees engage in job crafting. International Journal of Wellbeing, 3(2), 126-146. https://doi.org/10.5502/ijw.v3i2.1

Spurk, D., Hirschi, A., \& Dries, N. (2019). Antecedents and outcomes of objective versus subjective career

Stauffer, S. D., Abessolo, M., Zecca, G., \& Rossier, J. (2019). French-language translation and validation of the protean and boundaryless career attitudes scales: Relationships to proactive personality, career adaptability, and career satisfaction. Journal of Career Assessment, 27(2), 337-357. https://doi.org/10.1177/1069072717748962

Stauffer, S. D., Abessolo, M., Zecca, G., \& Rossier, J. (2019). French-language translation and validation of theprotean and boundaryless career attitudes scales: Relationships to proactive personality, career adaptability, and career satisfaction. Journal of Career Assessment, 27(2), 337-357. https://doi.org/10.1177/1069072717748962

success: Competing perspectives and future directions. Journal of Management, 45(1), 35-69. https://doi.org/10.1177/0149206318786563

Sultana, R. (2020). Nexus between Protean Career Attitude, Individual and Organizational Related Outcomes: Does Intelligent Career Framework Provide and Answer? (Doctoral dissertation, COMSATS University, Islamabad.).

Thijssen, J. G., Van der Heijden, B. I., \& Rocco, T. S. (2008). Toward the employability-link model: current employment transition to future employment perspectives. Human Resource Development Review, 7(2), 165-183.

Van den Broeck, A., De Cuyper, N., Baillien, E., Vanbelle, E., Vanhercke, D., \& De Witte, H. (2014). Perception of organization's value support and perceived employability: insights from self-determination theory. The International Journal of Human Resource Management, 25(13), 1904-1918

Volmer, J., \& Spurk, D. (2011). Protean and boundaryless career attitudes: Relationships with subjective and objective career success. Zeitschrift für ArbeitsmarktForschung, 43(3), 207218.

Wang, H. J., Chen, X., \& Lu, C. Q. (2020). When career dissatisfaction leads to employee job crafting. Career Development International, 25(4), 337-354. https://doi.org/10.1108/CDI03-2019-0069

Wiernik, B. M., \& Kostal, J. W. (2019). Protean and boundaryless career orientations: A critical review and meta-analysis. Journal of counseling psychology, 66(3), 280

Wiernik, B. M., \& Wille, B. (2017). Careers, career development, and career management. The SAGE handbook of industrial, work, and organizational psychology, 3

Wrzesniewski, A., \& Dutton, J. E. (2001). Crafting a job: Revisioning employees as active crafters of their work. Academy of management review, 26(2), 179-201.

Zafar, J., \& Mat, N. B. (2012a). Protean Career Attitude, Competency Development \& Career Success: A Mediating Effect of Perceived Employability. International Journal of Academic Research in Business and Social Sciences, 2 (4), 204-223.

Zhang, F., \& Parker, S. K. (2019). Reorienting job crafting research: A hierarchical structure of job crafting concepts and integrative review. Journal of Organizational Behavior, 40(2), 126-146

Zhou, T., Li, H., \& Liu, Y. (2010). The effect of flow experience on mobile SNS users' loyalty. Industrial Management \&Data Systems, 110(6), 930e946 